\title{
Biological Clock! Separate Day and Night
}

\author{
Eda Alemdar* \\ Medicine Faculty, Goce Delcev University, North Macedonia \\ *Corresponding author: Eda Alemdar, Goce Delcev University, Medicine Faculty, North Macedonia
}

\begin{tabular}{|c|c|}
\hline ARTICLE INFO & ABSTRACT \\
\hline Received: 幽 January 27, 2020 & \multirow{4}{*}{$\begin{array}{l}\text { Many diseases occur at certain times and after a specific process. Their treatment } \\
\text { also needs to be done at a particular time. This specific time is because external factors } \\
\text { are among the causes of many diseases. Some seasonal times and environments make } \\
\text { up diseases. External factors are the planets, the sun, the Moon, the seasons and the } \\
\text { day and night cycle. In parallel with the type of disease, their treatment also requires a } \\
\text { specific process and period. Treatments not made at the right time and in the right place } \\
\text { do not yield results. This study aims to determine the biological clock for the treatment } \\
\text { of diseases and to achieve the healthiest result in the way the circadian rhythm works. } \\
\text { In our research, classical medical data and modern medical studies were evaluated } \\
\text { together, and the various method was used in the article. The overwhelming majority of } \\
\text { studies on the subject are about that the biological clock has a certain time period per } \\
\text { day. In this study, it was revealed that there are two hours of the day, and night, which we } \\
\text { call biological hours for the treatment of diseases. }\end{array}$} \\
\hline Published: 幽 February 05, 2020 & \\
\hline $\begin{array}{l}\text { Citation: Eda Alemdar. Biological Clock! } \\
\text { Separate Day and Night. Biomed J Sci \& Tech } \\
\text { Res 25(2)-2020. BJSTR. MS.ID.004189. }\end{array}$ & \\
\hline $\begin{array}{l}\text { Keywords: Diseases; Biological Clock; } \\
\text { Classical data; Modern Studies; Nigh; Day }\end{array}$ & \\
\hline
\end{tabular}

\section{Introduction}

It is known that there are a biological clock and circadian rhythm in line with the structure and environmental relationship of the human body. The biological clock is connected to all dimensions of human life. In this respect, the process of staying healthy and knowing the biological clock in the treatment of diseases and the treatment during these hours are the most significant factors in reaching a lasting result. There is a specific and orderly functioning in the physical and psychological functions of generally living beings, particularly humans. The biological clock happens in this natural control and timer system. All events and developments, such as the change and development of plants, the life cycle of animals, are directed, shaped, and happened by the biological clock, which is linked to its particular natural structure. Thanks to the biological clock, which is very important for the human body, the whole system works, working of the cells is regulated; activities such as body temperature, hunger, sleep always work according to this order.

The proper functioning of the biological clock is essential for all organs of the body to function correctly and be healthy. The findings of the studies on the effect size of age, gender, ethnic, genetic and other factors in shaping the biological rhythm [1] show that, each of these factors cannot have a direct effect just to shape the outcome itself or to connect a specific reason. For example, when the cognitive process is discussed, research findings examining the relationship between the biological clock and cognitive processes are contradictory. These contradictory findings arise from the nature of the subject. Indeed, Liu's research shows this. According to him, both biological clock and cognitive processes are affected by many factors, genetically and environmentally [2]. Various factors may affect circadian rhythm and cognitive processes simultaneously and at different rates. Therefore, according to the research conducted by Cnrko and Dogutepe, it seems very difficult to keep all of these factors under control $[3,4]$. This makes it difficult to determine the biological clock.

\section{Biological Clock and Cosmos}

According to Dogutepe who summarized the researches on the effectiveness of internal and external factors in shaping the biological clock, external factors are more active here. According to researchers such as Paganelli and Liu, the internal clock is more driven by the influence and contribution of external phenomena [5-7]. According to Liu's study, seasons affect the physiological and psychological dimensions of people. This situation affects as well as healthy people, also people with health problems more preponderantly $[8,9]$. The contribution of the season, which is the manifestation of a solar cycle as an external factor, to human health is accepted by researchers such as Meesters [10]. According to similar 
studies [11,12], Seasonal environment, birth rate, and sperm count are influential in pneumonia, bronchitis, and influenza epidemic. In some places and situations, the change in air temperature can have fatal consequences.

In addition to the seasonal effect of the sun's cycle, some researchers have suggested the effect of the Moon's motion and cycle on the Earth, livings, and human beings [13-15]. Due to the heterogeneity of samples related to the diversity, environmental and chronobiological conditions of species, the analysis and comparison of the lunar cycle rhythm and time is not clear, research on the interaction of circadian and lunar cycle times develops an interesting and unique perspective on the coordination between different timing mechanisms [16,17]. Seasonal changes and phenomena, findings of research on the lunar cycle, reveal the relationship and effect of the Moon and the livings in the world [18]. The findings of suggest that the same biological cycle proliferation observed in some plants and aquatic animals may be preserved among various species, including Homo sapiens [19]. As a matter of fact, according to Chakraborty's research, the lunar cycle is one of the main factors of variable human psychology $[20,21]$.

The relationship between the Moon and living was the center of interest for the classical Muslim physicians, and they considered this connection in their treatment [22]. For example, Akşemseddin (d. 863/1459), advised his patients to take drugs for medical purposes on an empty stomach every morning, first new fifteen days of each month, that is, in the first half of the month [23]. Also, el-Biruni (d. 453/1061) and el-Kindi (d. 252/866) said that operations should be performed according to the cycle of the Moon [24]. According to İbrahim Hakkı (d. 1194/1780), who is from Erzurum in Turkey, in the first half of the month, the brain tissues of living things increase, and in the second half, it decreases. In Muslim medical studies in classical period, it is accepted that a certain period, which is shaped by the effect of planets, sun, and Moon on the Earth, is the most appropriate time for the functioning of the human physiological structure. This is called the natural rhythm of the biological clock according to recent medical data [26,27].

The biological clock shaped by the influence of planets, sun, and Moon is also under the control of day and night. Certain times of both night and day have a positive-negative effect on human physiology. In this respect, the classical period, physicians have emphasized that the treatment should be done in the last third of the night to obtain positive results in terms of health. However, performing this treatment should be in the first part of the month (first fifteen days), which includes phase after the full Moon (This is the last fifteen days for surgery). According to these data, the time zone (Biological time), which is suitable for the treatment of diseases, is the time when the night ends (Zodiacal Light) and the time when the sun is about to sunset. It is also necessary to consider the variability of this period according to seasons and regions.

The biological clock, which is the most critical factor for the treatment of human life, health, and diseases, is found two times in a day as day and night, within 24 hours of the day. In this case, the time of the biological clock changes continuously in the day and night cycle according to the seasons. This reveals that the biological time of "day" and the biological time of "night" are different. In some recent studies on the subject [28] is supported. Accordingly, contrary to opinions that the biological clock is only at one time of the day. The determination of the biological time of day and night varies according to seasons and regions.

\section{Conclusion}

In scientific studies on biological clock, it was emphasized that there are internal and external factors affecting the physical and psychological life of man. They divided the activities of the human body, organs and hormones into certain time zones "daily". They made this distinction over 24 hours. In these studies, on biological clock, it was emphasized that the most efficient clock related to human health is in a single time frame per day. However, life consists of day and night. There are cells that work day and night. For example, the 'pienal body works at midnight. According to us, there are two different times in the day and night period and that the biological time containing the most suitable time for treatments exists in these two time periods. In order to get the best results in human treatment, the most suitable biological clock is the time closest to sunset and the last third of the night before sunrise. These two time periods change according to summer and winter, region and continent, the long and shortness of day and night.

\section{Conflict of Interest}

The author declares that they have no competing interests in publishing this article.

\section{References}

1. Yadav A, Verma P, Singh S (2017) Going beyond the limits: Effect of clock disruption on human health. Biological Rhythm Research 48: 693-700.

2. Liu F, Chang HC (2017) Physiological links of the circadian clock and biological clock of aging. Protein Cell 8(7): 477-488.

3. Crnko S, Ernens I, Laake LWV (2018) New dimensions in circadian clock function: the role of biological sex. Cardiovascular Research 114(2) 1: 203-204.

4. Dogutepe ED (2010) The effects of biological clock and anxiety on basic cognitive functions. Ankara: Hacettepe University Social Science Institute.

5. Paganelli R, Petrarca C, Di Gioacchino M (2018) Biological clocks: their relevance to immune-allergic diseases. Clinical and Molecular Allergy 16(1): 2-8.

6. Liu F, Chang HC (2017) Physiological links of circadian clock and biological clock of aging. Protein Cell 8(7): 477-488.

7. Dogutepe ED (2010) The effects of biological clock and anxiety on basic cognitive functions. Ankara: Hacettepe University Social Science Institute.

8. Liu F, Chang HC (2017) Physiological links of circadian clock and biological clock of aging. Protein Cell 8(7): 477-488.

9. Yadav A, Verma P, Singh S (2017) Going beyond the limits: Effect of clock disruption on human health. Biological Rhythm Research 48: 693-700.

10. Meesters Y, Duizer WB, Hommes W (2018) The effects of low-intensity narrow-band blue-light treatment compared to bright white-light 
treatment in seasonal affective disorder. Journal of Affective Disorders 232: 48-51.

11. Singh PK, Tripathi NS, Byadgi PS (2011) Effect of Season on Prakriti. Germany: LAP Lambert Academic Publishing.

12. Senel F (2008) Biological Clock. Journal of Science and Technique 493: 58-67.

13. Della M, Atzori G, Dijk DJ (2015) Effects of lunar phase on sleep in men and women in Surrey. Journal of Sleep Research 24(6): 687-694.

14. Chakraborty U (2018) Effects of different phases of the lunar month on living organisms. Biological Ryhtm Research.

15. Chakraborty U (2014) Effects of different phases of the lunar month on humans. Biological Rhythm Research 45 (3): 383-396.

16. Takemura A, Rahman MS (2010) External and internal controls of lunarrelated reproductive rhythms in fishes. Journal of Fish Biology 76(1) $7-26$.

17. Raible F, Takekata H, Tessmar KR. (2017). An overview of monthly rhythms and clocks. Front Neurol 8: 189.

18. Tokgoz H, Yalcinkaya S, Islamoglu E, Karamik K, Tokgoz O, et al. (2017) Lunar cycle may affect shock wave lithotripsy related pain outcome. Ghana Med J 51(4): 181-186

19. Reinberg A, Smolensky MM, Touitou Y (2016) The full Moon as synchronizer of circa-monthly biological rhythms: Chronobiologic perspectives based on multidisciplinary naturalistic research. Chronobiol Int 33(5): 465-479.

20. Chakraborty U (2018) Effects of different phases of the lunar month on living organisms. Biological Rhythm Research.

\section{ISSN: 2574-1241}

DOI: 10.26717/BJSTR.2020.25.004189

Eda Alemdar. Biomed J Sci \& Tech Res

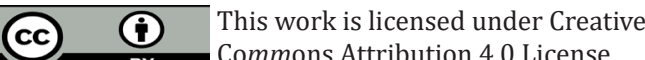

Submission Link: https://biomedres.us/submit-manuscript.php
21. Yousfi NR, Raouf N, Eirale C, Whiteley R, Farooq A, et al. (2018) Lunacy revisited - the myth of the full Moon: are football injuries related to the lunar cycle? Chronobiology International 35(10): 1385-1390.

22. Ibn Sina (2017) Al-Kanun fi al-Tib. trs. E. Kahya. Ankara: Center of Ataturk Culture Press 4: 208-211; Biruni AR (und.). Al-Kitab al-tafhim fi alSinaat al-tancim. Istanbul: Topkapi III. Ahmet Library (manuscript). No: 003477; Ahmad Al-Sani, Muhammad Mumin al-Husayni (und). AlMuhlisin fi al-Tarjamati Tuhfati al-Muminin. trans. Ahmad Sani b. Hasan Afandi (manuscript). 32.

23. Aksamsaddin MIA (1271) Madda al-hayat. (manuscript). Istanbul: Suleymaniye Library, Vahbi Afandi Sect. No: 1462.

24. Turner HR (2006) Science in medieval Islam: An illustrated introduction. Texas University Press.

25. Ibn Sina (2017) Al-Kanun fi al-Tib. 1: 146, Aksamsaddin MIA (1271). Madda al-hayat. (manuscript), 156; Arzurumlu IH. (1981). Marifatnama. Istanbul: Elif Ofset Press; Ahmad Al-Sani. Al-Muhlisin fi al-Tarjamati alTuhfati al-Muminin, 32.

26. Park MK, Freisling H, Huseinovic E, Winkvist AHI, Crispim SP, et al (2018) Comparison of meal patterns across five European countries using standardized 24-h recall (GloboDiet) data from the EFCOVAL Project. European Journal of Nutrition 57(3): 1045-1057.

27. Silver R (2018) Cells have sex chromosomes and circadian clocks: Implications for organismal level functions. Physiology \& Behavior 187: 6-12.

28. Yimit A, Adebali O, Sancar A, Jiang Y (2019) Differential damage and repair of DNA-adducts induced by anti-cancer drug cisplatin across mouse organs. Nat Communications 10(1): 309.

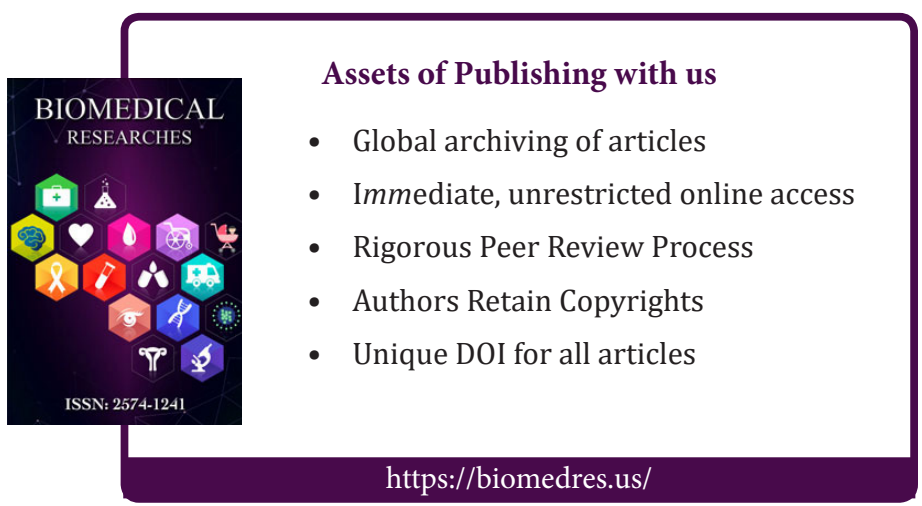

